\title{
Effect of Develop Strategy, Ethical Climate, on Quality Service to Customer Experience With Local Wisdom as a Moderating Variable
}

\author{
Golan Hasan* \\ Universitas International Batam \\ Batam, Indonesia \\ *golan.hasan@uib.ac.id
}

\author{
Farida Jasfar, Robert Kristaung \\ Universitas Trisakti Jakarta \\ Jakarta, Indonesia
}

\begin{abstract}
Research objective is to analyze whether local wisdom can moderate service quality with several variables involved, including developing strategy, service quality, customer experience, dimensions involved in this research are identifying the customer needs improvement strategy, and how the role of the government in supporting service quality by looking at the dimensions of interaction, education, entertainment, escapism, esthetic, network and outcomes. Local wisdom is a part of moderation in this research to be able to see the extent of the role of government and star hotels to respond wisely that has been passed down by its predecessors. Research method used in this study is the quantitative method and survey techniques. Number of samples needed in this study were 98 respondents given in the form of direct questionnaires and also through electronic media. Respondent was head and director of star hotel in Riau Islands. Processing was performed using Smart PLS. Results of this study are getting better if service quality is significantly positive with local wisdom and able to development of strategies to better support the tourism industry. Managerial implications in this study are to provide better information for relevant agencies in order to be able to maintain as a friendly national identity and also cultural and ancestral heritage by being positive in supporting the tourism industry.
\end{abstract}

Keywords-develop strategy, ethical climate, service quality, local wisdom, customer experience

\section{INTRODUCTION}

Riau Islands, especially Batam, has a very rapid development that has led to better economic growth, in which many office facilities, malls and hotels are also being developed very rapidly. The development of this development that requires quality in service, good service will produce good quality to achieve the goals of an organization, so that it can provide maximum impact for the development of an area where people who feel treated well will feel comfortable and satisfied [1]. Batam's position as one of the gateways for foreign tourists provides more value for workers in Batam to do their best in every service performance of the company or in public services. Development and modernization are also very influential in facing services so that they will provide more and more job opportunities [2]. Work issues can be resolved well, with the large number of visitors coming to the Riau Islands, especially Batam, and the more social conflicts they face. Business competition will also be increasingly numerous, especially for the level of occupancy or lodging and hotels that provide a variety of ease of service to imagine that customers will be satisfied with the services provided. Batam is still a tourist destination for foreign tourists, where for the number of star hotels around 59 of the total star hotels in Riau Islands are 118. Tanjung Pinang as the provincial capital of the Riau Islands has 21 number of star hotels but in Tanjung Pinang itself does not yet have star class hotels 5 . Based on the table above, the Riau Islands opportunity to increase the number of tourists is very large by collaborating from various parties to support each other. Especially in placing the right marketing channel in every tourism promotion. Good advertising will also support the promotion of tourism so that it can increase the interest of consumers to feel happy [3], and try to find satisfaction in being able to feel good service quality to the needs and comfort in the tourism industry. Government has tried to play an active role in launching "Visit Batam 2020" while maintaining existing local wisdom [4]. Collaboration in every field, especially in the field of tourism, is developed throughout the region, involving all relevant elements. The number of islands and the number of attractions that can be introduced to be developed, as well as the many potential tourist destinations not only nature, such as dock tourism, Batam-Rempang-Galang (Barelang) bridge tourism, religious tourism, shopping tourism, culinary tourism. Many things can be done well to preserve local wisdom in the Riau Islands, especially Batam, for example there are several places in Batam that are given foreign names for example, the Nagoya area, Nagoya Newton, Greenland, Orchid Park, Windsor Phase. Nagoya Point, Point Center This is because many tourists visit Batam, local names and places should not be given foreign names, and it is feared that they will further develop so as to 
eliminate many local wisdom in the Riau Islands. Another effect is that many business people in Batam use marketing transactions using foreign exchange and this is evidenced by the large number of money changers in Batam and surrounding areas. $\mathrm{n}$ addition to a good strategy in local government support services, it is also important to give input to every business person to improve performance to always maintain cleanliness and to pay attention to policies in every business and production to become a better togetherness. Tourism actors such as hotels and micro businesses can also be considered and are able to make a positive contribution to supporting the tourism industry.

\section{LITERATURE REVIEW}

\section{A. Grand Theory}

Grand Theory is a term coined by C. Wright Mills in the sociological imagination (1959) to refer to a very abstract form of theory in which organization and conceptual arrangement are prioritized rather than understanding the social world. Grand Theory emphasizes the concept of balance, decision making, systems and forms of communication as a basic means of regulating in the study and analysis of a relationship between existing theories. Grand Theory is also a theoretical foundation which is a guide to get the right direction in conducting scientific research, so that researchers in referencing existing literature and literature will get a strong theoretical and empirical basis for developing hypotheses and developing research models that are expected and desired by researchers [5].

Develop Strategy is how the strategy of service development and improving what is given to the needs of individuals [6]. Cheng [7] in his article "Service quality, Attractive quality, and Competitive quality" states that every organization creates limitations in developing strategy development, because many things happen are caused by developments that are only done by leaders or managers, because all decisions can only be made by top leaders without regard to subordinates or the surrounding environment. What should be good is the development of a better strategy that is to establish references from as well as a lot of literature so that service and quality can be better [7]. How a company is able to survive by innovating to face competition. Development in strategy is an economics that places how to make a good change to produce business formulas for the progress of an organization that can support the wants and needs of members so that organizational goals are achieved. Previous researchers also explained that strategic development is closely related to firm performance [8], so that it is an indicator of the success of a company or organization, especially in a local government that has a strong culture to be implemented [9]. Ethical climate depicts a small regional population making organizational ethical climate based on tasks related to norms, laws, rules and policies characterize underdeveloped regions [10]. In the public sector something that stands out from individual perceptions about climate ethics is related to regulations and codes of ethics in every organization. Together these organizations can go hand in hand. "Business environment, Organizational justice, Business ethics, Ethical climate, Ethical behavior, Intracultural analysis, Working organizations Paper [10]. Quality of service [11] is a measurement and quality improvement to improve service quality that is even better for consumers. Service quality is also a measure of how good the level of service delivered is in accordance with the expectations desired by the customer [12]. Service quality is an expectation of the company to fulfill desires and expectations [13]. The quality of government services in this case the regional offices of culture and tourism, has a role to provide the best quality of service for tourists visiting an area, especially in the Riau Islands, especially Batam as one of tourist destinations in Indonesia.

Customer experience is a big key in a big key in a business or company, customer experience depends on the services provided to customers from a company [14]. Relationship with the quality of government services in this case the regional offices of culture and tourism, is very instrumental in providing the best quality of service for tourists visiting an area, especially in the Riau Islands, especially Batam as one of the tourist destinations in Indonesia. Customer Experience describes how the experience of service quality by seeing from various angles including education, entertainment, esthetic escapism, network and outcomes [15-17]. Theory of how the role of government in doing the best service for the community so as to be able to maintain all policies well so that it can be sustainable.

Previous theories, as well as opinions about local wisdom or local wisdom are local (local) thoughts or ideas that contain wise, creative, wholesome, internalized values (traditions). These values are believed to contain the truth so that it is followed by members of the community. This local wisdom is called the noble values of society that serves as a good philosophical foundation towards harmonization [18-21]. Local wisdom can be interpreted as good and right values where this hereditary activity is carried out by the community concerned as a result of interactions between humans and their environment [9,22]. According John et al. [23] local means local while wisdom is wisdom. In general, local wisdom can be understood as local ideas that can be understood to be wise, full of wisdom, of good value, embedded and followed by members of the community.

Middle Range Theory is a theory that is used as a hypothesis that is worth testing between research variables. Not as a device that regulates relationships in social science studies. Middle Range Theory is a series of ideas / ideas that are interconnected and focus on a limited dimension, namely on local wisdom. Middle Range Theory explains specific phenomena and has been tested in research and used to guide local wisdom in the community. Middle Range Theory, describes how people use objects and structures and human behavior related to their use in disclosure that can explain phenomena at the community level. This research uses Middle Range Theory: local wisdom 


\section{B. Research Paradigm}

Grand theory summarizes the main theories that connect all variables in research. Middle range theory explains the theory underlying one or several variables in our research that is within the scope of the grand theory.

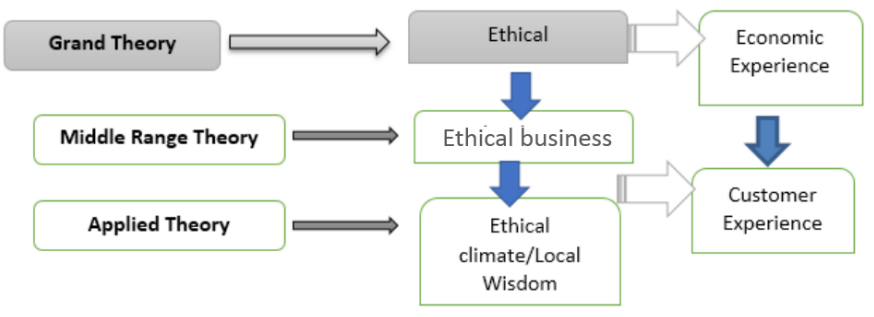

Fig. 1. Effect of develop strategy, ethical climate, on quality service to customer experience with local wisdom as a moderating variable (sourced: data processed)

\section{METHODS}

Research will use survey techniques, deductive and quantitative approaches [24]. The deductive approach aims to test the theory through the collection of data from respondents then the application is carried out and observed with a statistical test. The quantitative method focuses on collecting data according to the problem and the number of population and analyzing the data. This study Hemmington et al. [25] is a testing hypothesis that aims to explain the nature of the relationship between two or more variables [26]. In this study also tested the hypothesis of the influence of Develop Strategy (DS), Ethical Climate (EC) on Customer Experience (CE) mediated by Service Quality (SQ) and moderated by local wisdom. In this study is a survey research [27], where by gathering information from or about individuals who will be described, compared, or explained about knowledge of attitudes and behaviors. Respondents in this study are tourism practitioners who are directly involved in maintaining local wisdom as hospitality management, including: Director, Deputy Director, General Manager starred in Batam and Riau Islands. The number of Batam-Kepri-starred hotels is 118 starred hotels. Researchers used census or saturated sampling methods. This method is used by researchers to take all populations to be sample of the hypotheses that are in:

$\boldsymbol{H} \boldsymbol{1}=$ Develop Strategy has a positive effect on Service Quality

The path analysis test for the develop strategy variable to service quality has a P-Value of 0.00 smaller than 0.05 so that the develop strategy variable understands the desire of every community to convince every service office and hotel to be able to maintain the best possible service quality how to conduct services with the best possible partners, the addition of service quality is not only in the office or hotel, but also involves the community and the fostered partners so as to be able to provide positive innovation, investment in services is very influential on the quality of service so as to provide flexibility for tourists coming to the destination - new tourist destinations that can provide curiosity and a sense of satisfaction with the good environment.

\section{$\boldsymbol{H} \mathbf{2}=$ Develop Strategy has a positive effect on Customer} Experience

Government experience in this matter the department of culture and tourism related to what is the government program in Batam-Riau Islands in welcoming the "visit Batam 2020" [4]. Improving the quality of service will have a good impact on the progress of an area, the development will make the area have special characteristics and provide opportunities for tourists to visit the area so as to be able to add to the economy, especially in the field of tourism. The strategy of developing an area has an impact on society.

\section{H3 = Ethical Climate has a positive effect on Service Quality}

Ethical climate of each individual seen from the attitude and personal can bring a relationship to a service [28] as well as the role of the private sector to develop quality services to increase economic growth by keeping the tourism sector as good as possible an important part of the Riau Islands.

$\boldsymbol{H 4}$ = Ethical Climate has a positive effect on Customer Experience

It means that the ethical climate influences customer experience provided. The quality of government services can also be done with a number of contributions developed by taking into account opportunities for the utilization of other resources [29]. The development of the tourism industry with the surrounding support are interrelated to the ethical climate and the government will bring a positive impact on the influence of tourist arrivals.

H5 = Local Wisdom influences Develop Strategy on Service Quality.

Local wisdom variable strengthens the influence on develop strategy and service quality, this is the step of improvement to maintain the existence of local wisdom in the community. The influence of extraordinary foreign culture can cause local wisdom to slowly disappear. Local wisdom is how people provide good policies and culture for future generations.

H6 = Local Wisdom has a positive effect on Service Quality.

Existing local wisdom should be maintained properly, what is needed here is how the role of each party to maintain local wisdom that has been passed down by the predecessors, because local wisdom has indeed existed from generation to generation. So what is needed is how the role of each institution to preserve and preserve culture is not to develop an existing culture so that the culture does not mix with a foreign culture that is not necessarily suitable to be a culture in an area [30,31]. Maintaining a tradition or culture will be very difficult if only to develop without seeing the origin of where the culture is located. Existing local wisdom and almost regressed due to lack of cooperation from all parties, especially the local 
community which began to be influenced by negative foreign cultures so that many young people sometimes do not know local wisdom and even norms that must be maintained as Indonesian society which has many diverse local wisdom.

$\boldsymbol{H 7}=$ Local Wisdom has a positive effect on Customer Experience

Experience of government participation to safeguard local wisdom must be maximized because many potential areas that are not well touched by local wisdom. The tourism sector that has been developed by the government only relies on tourism destinations without preserving local wisdom. The cultural aspect has so far been overlooked by the government so that the private sector, especially hotels, lacks a local touch to its existence. Many tourist destinations that have been sold by the government but do not maintain local wisdom properly.

\section{DISCUSSION}

Test results for descriptive statistics for each indicator were also carried out. Variables are measured from the develop strategy, the dimension is identify customer's need, improvement, Variables are measured from Ethical Climate, the dimension is egoism. Benevolence, principle, Variables measured by service quality, the dimensions are tangibility, reliability, responsiveness, assurance, empathy. Dimensions measured from local wisdom are mutual cooperation, linguistic anthropology, and variables measured from customer experience education, entertainment, escapism, esthetic, network, outcomes. the value of the effect size $\mathrm{f}^{2}$ for local wisdom is 0.363 . Local wisdom as a moderating variable has a moderate influence on the structural level.

\section{CONCLUSION}

The results of this study conclude that in general the development of strategy, ethical climate and service quality are variables that influence the experience of participation and local wisdom also have a good influence on customer experience. The moderation of local wisdom on quality and experience also needs to be considered in subsequent developments, while the conclusions in this study are: 1.) Develop Strategy, significant and positive effect on service quality, the purpose of this positive influence is the role of improvement and development of strategies carried out on service quality is good and needs to be further developed into a special standardization [32]. Develop Strategy, significant and positive to the customer experience, this illustrates that there is an effort from every service institution and also the hotel to continue to improve and develop a strategy for good service quality in the community, so that many tourist destinations can be sold well [33]. 3.) Ethical Climate has a positive effect on service quality, illustrating that the ethical climate greatly influences the conditions of service quality, behavior, attitudes will affect all aspects of service performed by each related agency so that it is able to provide maximum service in welcoming tourists, especially in maintaining local wisdom in star hotels. 4.) Ethical Climate has a positive effect on customer experience, this illustrates how the ethical climate also plays a role in government experience, much needs to be improved from government services by maintaining attitudes and behavior towards the community, especially how the government's role is to make tourists feel comfortable visiting Batam. -Riau islands. 5.) Significant service quality has a positive effect on customer experience, this illustrates that the role of the government to support each hotel and private parties to provide good experience by maintaining service quality. If fulfilled, it can support the government to increase the economy, especially from the tourism sector [34]. 6.) Local Wisdom weakens the influence of ethical climate on service quality, this illustrates that local influences weakly influence attitudes and behavior in the community so that service quality can be disrupted, affecting the level of tourist visits because the ethical climate is a part that should provide comfort for tourists foreigners who visit and how the community can also feel the level of satisfaction from the services provided. 7.) Local wisdom has a positive effect on service quality, in safeguarding local wisdom not to develop but maintain local wisdom. Because this is a hereditary inheritance from its predecessors, so that it is afraid of being disturbed by foreign cultures $[8,9]$. 8.) Local Wisdom moderates or strengthens the effect of service quality on customer experience, Local wisdom plays an important role in maintaining the experience of the government, there is hope for the community towards the government, especially in Batam, can continue to maintain local wisdom, for example by maintaining the traditional Malay clothes used on Fridays' at school and government agencies. Cultural activities such as the Kenduri Seni Melayu were able to elevate regional marwah so that it was well-known to foreign countries and invite foreign citizens to attend all activities with nuances of Malay so that the slogan "will not be lost Malay on earth" becomes a strong spirit to maintain local wisdom. 9.) Local wisdom has a positive effect on customer experience, the Government should try to work together with private parties, especially with star hotels in maintaining local wisdom, for example when foreign guests or tourists come to be given dances or special features from the region in the form of drinks or food, because many hotels and Private parties who come to Batam and the Riau Islands bring foreign culture, resulting in many areas in Batam using foreign terms. The placement of street names in Batam in particular began to apply the names of the famous Malay heroes or kings to Singapore, Brunei, Thailand and Malaysia. Utilizing strategic locations in dense areas by making small artifacts or monuments with Malay nuances such as traditional artifacts for fresh flour, Malay batik motifs that have special characteristics, also utilizing blank street walls with poems or twelve famous gurindam writings.

\section{A. Implications of Regulation}

This research is expected to be used as a control for the community with certain rules that must be obeyed so that it can improve the experience of government, among others:

Education, the field of education and teaching on knowledge of local wisdom can be applied starting from the 
basic level of the role of the government by adding books containing local culture so that people can realize that maintained local wisdom can improve services for tourists visiting regional tourist destinations. Entertainment, part of one of the attractions of tourist arrivals, by increasing regional tourism events that are characteristic of Malay or local specialties. Offering local entertainment that is rarely seen by tourists, such as the Kenduri Seni Melayu which is always done every year so that it can become a cultural event between nations in the Asean region. Escapism, Batam as one of the 3 tourism destinations in Indonesia is a place for foreign tourists, especially to let go of boredom in activities, especially Singaporeans who have very high levels of stress at work. Batam alternative as a destination to get rid of boredom from routine, has a positive impact on improving the economy of the tourism sector. The government experience will be better for fixing Batam, repairing, managing roads and infrastructure. Esthetic, the natural beauty of the Riau Islands and Batam in particular is a special charm for tourists who visit. The existence of beaches, kelong, and small islands such as Abang island is a shallow sea tourist destination with coral reefs, fish and marine life that are maintained. The beauty is not only from nature and the environment, but also involves the aesthetic experience of the command to invite people to connect with attitude, morals and intellectuals, so that aesthetics can be an impetus or motivation about the balance or texture of self-expression that expresses natural beauty.

\section{ACKNOWLEDGMENTS}

Many thanks to the academic community of Batam International University, thanks to Trisakti University especially the doctoral program, Faculty of Economics and Business. Thank you to Prof.Farida Jasfar as promoter, Dr. Robert Kristaung as co-promoter, Prof. Ijang, Prof. Yuzwar, Prof. Willy Arafah, Prof. Handoko, Dr. Teddy, Dr. Meilina, family and all those who have helped. Only God can repay you all.

\section{REFERENCES}

[1] Saha G.C., Theingi, "A study of low-cost airline carriers in Thailand," Serv Qual Satisf Behav intentions, Vol. 19, No. 3, pp. 350-372, 2009.

[2] G. Stamenkov and Z. Dika, "A sustainable e-service quality model," J Serv Theory Pract, Vol. 25, No. 4, pp. 414-42, 2015

[3] Batool and iqbal, "Impact of Green Advertising on Consumer Behavior," Int Interdiscip J Sch Res., Vol. 2, No. 1, 2016.

[4] Kepri PP. Portal Pariwisata Batam 2019 [Internet]. 2016. p. 2016. Available from https://arsipskpd.batam.go.id/batamkota/skpd.batamkota.go.id/pariwisat a/2016/05/19/tentang-pariwisata-kota-batam/index.html

[5] R. G, And J, Wiechmann JG. Marketing Corporate Image. Eleven Edi. Megraw-Hill-Professional, 2011

[6] R.A. Peterson and D.G. Berger, "Entrepreneurship in Organizations: Evidence from the Popular Music Industry," Adm Sci Q. 1971.

[7] Cheng, Article information : Int J Hotel Manag. 2018; emerald-sr

[8] S. Rahman S ur, M.A. Khan and Iqbal N, "Motivations and barriers to purchasing online: understanding consumer responses," South Asian J Bus Stud., Vol. 7, No. 1, pp. 111-28, 2018
[9] R. Pauluzzo, M. Guarda, L. De Pretto and T. Fang, "Managing paradoxes, dilemmas, and change: A case study to apply the Yin Yang wisdom in Western organizational settings," Cross Cult Strateg Manag., Vol. 25, No. 2, pp. 257-75, 2018.

[10] Stamenkovic et al. Intra-national diversity. Cross Cult Strateg Manag [Internet]. 2018;25(3):425-42. Available from: https://www.emeraldinsight.com/doi/10.1108/CCSM-05-2017-0061

[11] M.M. Ward, X. Zhu, M. Lampman and G.L. Stewart, International Journal of Health Care Quality Assurance Article information: To cite this document : 2015 ;

[12] J.M.M. Joudeh and A.O. Dandis, "Service Quality, Customer Satisfaction and Loyalty in an Internet Service Providers," Int J Bus Manag., Vol. 13, No. 8, pp. 108, 2018

[13] R. Qaiser Danish, A. Afzal Humayon, H. Javaid Iqbal, S. Raza and J. Shahid, "The Impact of Service Quality and Service Value on Customer Satisfaction through Customer bonding: Evidence from telecommunication Sector," Eur Online J Nat Soc Sci. Vol. 7, No. 1, pp. 40-7, 2018

[14] Haemoon, Fiore AM, Jeoung M. Measuring experience economy concepts: Tourism applications. J Travel Res., Vol. 46, No. 2, pp. 119 32, 2007.

[15] A.W. Wiseman and E. Anderson, Annual Review of Comparative and International Education 2013. In 2013. p. iii.

[16] H.S. Al-Hubaishi, S.Z. Ahmad and M. Hussain, "Exploring mobile government from the service quality perspective," J Enterp Inf Manag. Vol. 30, No. 1, pp. 4-16, 2017.

[17] R. Sanchez, J. Galbreath and G. Nicholson, Building sustainability competence from the top down: A model for researching and improving boards of directors' influence on firms' sustainability performance. In: ron sanchhez, jeremy galbreath gavin nicholson, editor. Research in Competence-Based Management. seventh ed. USA: emerald subsciption provided by emerald-srm: $387340 ; 2017$. p. 69-107.

[18] A. O’Donnell, “Small firm marketing: Synthesising and supporting received wisdom," J Small Bus Enterp Dev., Vol. 18, No. 4, pp. 781805, 2011.

[19] Wagiran, "Pengembangan karakter berbasis kearifan lokal," J Pendidik Karakter, Vol. II, No. 3, pp. 329-39, 2012.

[20] M. Primyastanto and S.M.S.A. Efani, "Fisheries Resources Management by Empowering the Local Wisdom in Madura Straits," Res Humanit Soc Sci. Vol. 3, No. 6, pp. 13-21, 2013.

[21] R. Kriyantono, Teori Public Relations Perspektif Barat Dan Lokal: Aplikasi Penelitiandan Praktik. Jakarta: Kencana. Jakarta: Kencana; 2014, pp. 67-78.

[22] J. Lu, S. Liu, L. Cui, L. Pan and L. Wu, "Crowd wisdom drives intelligent manufacturing," Int J Crowd Sci., Vol. 1, No. 1, pp. 39-47, 2017.

[23] John M, Ii AP, Robinson RB, Ii P, John A, Ii AP, et al. Strategic management $=$ manajemen strategis $:$ formulasi, Strategic management = manajemen strategis $:$ formulasi, Strategic management $=$ manajemen strategis : formulasi, implementasi, dan pengendalian buku 1 / John A . Pearce II , Richard B . II second. New York: McGraw- Hill Book: 658.4012 PEA s Pearce II.John A. Jakarta Salemba Empat; 2018. 654 p.

[24] S. Rahi, "Research design and methods: A systematic review of research paradigms, sampling issues and instruments development," Int $\mathrm{J}$ Econ Manag Sci., Vol. 6, No. 2, pp. 1-5, 2017.

[25] N. Hemmington, P. Kim and C. Wang, "Benchmarking hotel service quality using two-dimensional importance-performance benchmark vectors (IPBV)," J Serv Theory Pract., Vol. 28, No. 1, pp. 2-25, 2018.

[26] D.R. Cooper and P.S. Schindler, Business research methods. 12th ed. New York: McGraw-Hill, 2014

[27] S. Alaaraj, Z.A. Mohamed, U.S.A. Bustamam, "External growth strategies and organizational performance in emerging markets: The mediating role of inter-organizational trust," Rev Int Bus Strateg., Vol. 28, No. 2, pp. 206-22, 2018. 
[28] V. Nedkovski, M. Guerci, F. De Battisti and E. Siletti, "Organizational ethical climates and employee's trust in colleagues, the supervisor, and the organization," J Bus Res., Vol. 71, pp. 19-26, 2017.

[29] J. Mulki and F.G. Lassk, "Joint impact of ethical climate and external work locus of control on job meaningfulness," J Bus Res., Vo. 99(February 2018), pp. 46-56, 2019.

[30] J. Caraballo-Cueto, "Free trade zones, liberalization, remittances, and tourism, for what?: Jobless growth in the Dominican Republic," Int J Dev Issues. Vol. 15, No. 2, pp. 181-200, 2016.

[31] I.R.A.P. Jati, Local wisdom behind tumpeng as an icon of indonesian traditional cuisine. Nutr Food Sci. 2014.
[32] F. Davidoff, M. Dixon-Woods, L. Leviton and S. Michie, "Demystifying theory and its use in improvement," BMJ Qual Saf., Vol. 24, No. 3, pp. 228-38, 2015.

[33] T.T.N. Nguyen and T.M.N. Luu, "Linking transformational leadership and organizational performance: An empirical investigation of manufacturing firms in Vietnam," Econ Sociol., Vol. 12, No. 2, pp. 17091, 2019.

[34] Kusumadmo, Manajemen Strategik Pengetahuan. In: Thomas I Wheelen and JDH, editor. seventh ed. USA: Bina Rupa Aksara 2015; 2015. p. 254-6. 